\title{
Selection of Best Supplier by Using AHP Approach for Managing Risk Factors in Logistics: A Case of Leather Products Industry
}

\author{
Md. Abdul Moktadir ${ }^{1,2 *}$, Towfique Rahman ${ }^{2}$ and Razia Sultana ${ }^{1}$
}

${ }^{1}$ Institute of Leather Engineering and Technology, University of Dhaka, Dhaka-1209, Bangladesh

${ }^{2}$ Department of Industrial and Production Engineering, Bangladesh University of Engineering and Technology, Dhaka-1000, Bangladesh

\begin{abstract}
In the current competitive business environment today, leather products companies face numerous risks in the logistics network. Hence, managing logistics risks in the existing leather products supply chains are necessary to perform better in the global market. To overcome the logistics risks, best supplier section is one of the most crucial tasks for leather products companies. Therefore, an agile decision support framework is necessary for managing risks in logistics network. This study aimed to support leather products company's decision makers by selecting best supplier considering risks factors in logistics with the help of powerful Analytical Hierarchy Process (AHP) approach. It is a dynamic and very usable Multi Criteria Decision Making (MCDM) tool which can help decision maker to evaluate the best supplier when any supplier is unable to perform their tasks. In this research, we evaluated the best supplier by prioritizing of available suppliers with considering risks factors in logistics. This research will assist the leather products company's decision-makers to formulate some tactic and strategic policy to minimize the logistics risks.
\end{abstract}

Keywords: Risk management; Supplier selection; Logistics; Leather products industry; AHP

\section{Introduction}

Success in today's highly competitive manufacturing environment depends on the selection of best suppliers. Nowadays, supplier selection is one of the vital issues in leather products industry to improve manufacturing performances in the supply chains [1]. Customer satisfaction and the buyer demands largely depend on the best supplier selection. Best supplier selection helps to achieve highquality products at relatively lower costs with higher customer satisfaction and ultimately ensures profitability [2-4].

In leather products industry, the purchasing management always tries to reduce the number of suppliers and build a long-term relationship to minimize the risk. Further, the current trend of supplier management is to maximize the profit, and increase the operational performance and reduce the production risks. So, companies always try to select the vendor considering some criterion like the performance of the vendor, quality of the raw materials, the price of raw materials $[5,6]$.

Supplier risk management is defined as the process of anticipating and getting ready for the likelihood of factors which may antagonistically influence the supply chains. Logistics risk management is the management of networks for proper transportation of raw materials and finished goods. The need for proactive and predictive strategic policy is ever present in business today to minimize risks of supply chains and logistics networks [7-10].

Risk is an uncomfortable reality in manufacturing today and even the most sophisticated enterprises use to face the different types of threats. Logistics risk management includes disruption risk, operational risk, disaster emergency, logistics service risk management. A disruption is an unexpected event that disturbs normal flows of products and materials within a supply chain. Presence of uncertainties on supply, demand, market price, transportation time cause operational risk in logistics $[11,12]$. In the logistics service industry, third-party logistics (3PL) service providers and transportation and shipping companies face risks in their business operations.
Literature reveals that all of the previous research focused on vendor selection and logistics risk management, although there is no research conducting for supplier selection with considering logistics risks in leather products companies supply chain [13-15]. To overcome this gap, this research focuses on logistics risk management with respect to supplier selection. To manage and mitigate risk in logistics for supplier selection, the decision makers of leather products companies must consider multiple criteria. In this regards, an agile decision support framework for supplier selection is very necessary to mitigate the logistics risk factors.

To support the decision makers, this research considers a case company to select best suppliers among multiple available suppliers. Supplier selection is very crucial tasks. It becomes more challenging matter when some risks like walkout, transportation breakdown, strikes, and earthquakes etc. suddenly happened. Therefore this research arises some research question as follows:

\section{What are the selection criteria that should be considered?}

2. How can companies be evaluated and prioritize the best suppliers when selected supplier unable to supply materials?

To address this research question, following two objectives have been proposed.

1. Identify the most important criteria to supplier selection.

2. Selection of most suitable supplier with the help of AHP by prioritizing supplier when the sudden risk occurs.

This article contributes the existing literature by selecting best

*Corresponding author: Md. Abdul Moktadir, Department of Industrial and Production Engineering, Bangladesh University of Engineering and Technology, Dhaka-1000, Bangladesh, Tel: +8801821719283; E-mail: abdulmoktadir2010@gmail.com

Received September 11, 2017; Accepted October 06, 2017; Published October 11,2017

Citation: Moktadir MA, Rahman T, Sultana R (2017) Selection of Best Supplier by Using AHP Tool for Managing Risk Factors in Logistics: A Case of Leather Products Industry. Ind Eng Manage 6: 232. doi:10.4172/2169-0316.1000232

Copyright: (c) 2017 Moktadir et al. This is an open-access article distributed under the terms of the Creative Commons Attribution License, which permits unrestricted use, distribution, and reproduction in any medium, provided the original author and source are credited. 
supplier considering risk factor using powerful AHP tools. AHP models provide a better decision making framework to prioritize the supplier and to choose the best alternative supplier for that raw material to meet the uncertainties [16-17].This research helps to model a framework by considering some factors like keeping promise, technology, agility etc. and selecting best one when sudden logistics risk happens in the logistics networks. The modeling framework will test in real case example to justify the applicability of the current research. The proposed models will assist decision makers to avoid risk factors during the selection of the best supplier. As avoiding risk factors are very complex in nature, therefore this modeling decision support framework will help to avoid uncertainty in the logistics network.

The rest of the paper is structured as follows: the following Section depicts the details literature on supplier selection and risk minimization. Next Section shows the details of AHP methodology. Then it presents the real life case example. Then it describes the discussion and conclusion of the study. Finally, it shows the managerial implications direction of study.

\section{Literature Review}

The selection of a vendor for partnership is an essential advance in making an effective cooperation. For a better buyer-supplier relationship, it is mandatory to select the best supplier. If the supplier is adequately selected, higher quality materials, the better relationship is more achievable [18]. Supplier selection is characterized in as the "procedure of finding the providers having the capacity to give the buyer the correct quality items as well as service at the right price, in the proper amounts and at the right time [19]. In this research, we utilized a powerful and widely applicable AHP tool to choose the best supplier among numerous suppliers.

Existing literature shows that little research uses AHP tool for vendor selection considering risk mitigation in logistics [20]. Akarte et al. [21] considered 18 selection criteria to evaluate the casting supplier with the help of a web-based AHP approach. In the framework, to evaluate the suppliers, buyers had to determine the relative importance weightings for the criteria based on the casting specifications, and then assigned the performance rating for each criterion using a pair-wise comparison. Muralidharan et al. [22] developed a five-step AHP-based decision model to assist the evaluator to select the best supplier considering nine evaluating criteria. In this proposed model, different experts from purchasing department, store department, and quality control department were engaged to evaluate the supplier. Chan FTS [23] also suggested an AHP based decision model facilitate decision makers in selecting suppliers.

Chan et al. [24] proposed AHP model to assess the suppliers. In this model, he considered six main criteria and twenty sub-criteria of which the relative weights were calculated on the basis of the customer. In the model of Liu et al. [25], AHP model was used to evaluate suppliers. Similar to Chan, (2003) the authors did not apply the AHP's pair-wise comparison to determine the relative importance ratings among the criteria and sub-factors. Instead, the author utilized Noguchi's voting and positioning strategy, which enabled each manager to vote or to decide the request of criteria rather than the weights. Chan et al. [26] developed an AHP based model to assess the best supplier considering 14 criteria. In this model, a sensitivity analysis was also carried out to evaluate the response of decision alternative when the relative rating of each criterion was changed based on experts' opinion.
Hou et al. [27] proposed a decision support model using AHP approach for supplier selection in a mass customizations environment. In this model, he considered external and internal criteria to justify the needs of the market in the global environment. Lee et al. [28] developed a decision making frame considering some essential criteria like quality, pollution control, technology capability, , green production, environmental management, and ecological competency for the ecological supplier selection. Govindan et al. [29] investigated the supplier in the automobile industry. Aksoy et al. [30] examined the supplier in just-in-time (JIT) production environments.

Supplier selection is the key to obtaining the desired level of quality, on-time delivery, and at the right price; the necessary level of technical support; and the desired level of service. Buyers must take six important supplier-oriented actions in order to satisfy this responsibility. These are developed and maintain a viable supplier base, address the appropriate strategic and tactical issues, ensure that potential suppliers are carefully evaluated and that they have the potential to be satisfactory supply partners, decide whether to use negotiation as the basis of source selection, select the appropriate source [31]. Dargi et al. [32] developed a multi-objective programming model to select the optimal suppliers and determine the optimal order quantity. In this model, to evaluate the supplier performance five criteria were taken into account.

Finally, it can be concluded that a number of studies and researches are conducted on Supplier selection with multiple criteria, but there is not enough research and studies done on prioritizing suppliers with logistics risk factor. All the efforts were made to find the appropriate way to select alternative when selected supplier becomes unavailable. That is why here we have tried to solve this kind of important topic using the method named Analytic Hierarchy Process (AHP)

\section{Solution Methodology}

\section{Analytic hierarchy process (AHP)}

The analytical hierarchy process (AHP) system was introduced by Thomas Saaty in 1980 [16,17,33,34]. It is a very flexible and powerful tool for dealing with complex decision making, and helps decision makers set priority and make optimal decisions. Even though the AHP has the ability to make priority rankings based on expert knowledge. In AHP technique, there are two phases: develop the hierarchical model using considered criteria and evaluate the criteria on the basis of experts' inputs [35].

AHP is a dynamic and widely applicable tool for evaluating complicated multi-criteria decision making problems. It is used based on the attribute-based rating scale to assess the alternatives with the assistance of decision makers. The assessment of alternative largely depends on human judgments. It is a very effective technique for decision making in where some criteria are considered to evaluate the alternatives and which is very difficult to evaluate in real life without any MCDA tools. AHP helps to formulate the problems and assess the problem in less time [36,37]. In AHP method, first collected the decision variable with the help of experts and then build the comparison matrices among decision variable. Then the weights of decision variable and a consistency ratio (useful for checking the consistency of the data) computed from the decision matrices. In this study, AHP approach was employed to evaluate the best supplier of available multiple suppliers. The real life case example was also employed in this study for better understanding. 
The procedure of Analytical Hierarchy Process is described below for better understanding and applicability in real life multi-criteria decision making problems [38].

The steps involve in AHP process are given below:

Step 1: Define the objectives of the present work and formulate the decision support hierarchical framework for criteria and suppliers.

Step 2: Formulate the pair-wise comparisons matrices for the criteria and suppliers with the assist of comparison rating scale. From the feedback of experts from the case company helps to develop matrices among criteria and alternative suppliers. Pairwise comparison rating scale is given in Table 1 .

Step 3: Determine the weights, maximum Eigen value $(\lambda \max )$ and C.I (Consistency Index) of criteria and suppliers.

Step 4: Find the value of consistency ratio C.R =C.I/R.I. Where, R.I is taken from Table 2.

Step 5: With the help of step 4 determine all weights of criteria and suppliers. Then normalize the obtained weights and fix the final rank for the alternative suppliers.

Step 6: To select best supplier when sudden risk happens in the logistics network, consider some important criteria for selecting best suppliers from the remaining available suppliers.

\section{A Case Study}

Selection of best supplier is a crucial task to manage risks and for order processing timely. Hence, it is an important task to evaluate the best supplier by considering some important factors. Therefore, identifying the selection criteria is more necessary for selecting a supplier that can affect the overall performances of companies. In this research, some important criteria are identified which are used to formulate the decision support model. The identified criteria are quality improvement, least delivery time, IT in supply chain network, cost minimization, trust development etc. Suppliers must be prioritized on each of these factors because they all affect the total profitability and effective functioning of the company.

Company ' $\mathrm{XYZ}$ ' is one of the leading leather products manufacturing company which produces quality leather goods by maintaining the international standard. This company exports verities of leather goods in multiple developed countries within the scheduled time. The transportation of these finished products needs greater care to catch the buyers as well as customers. Therefore, this company wants to justify the current supply chain networks by considering some important supplier selection criteria. Hence, this company

\begin{tabular}{|c|c|}
\hline Rating & Linguistic attributes \\
\hline 9 & Extreme important \\
\hline 8 & Very strong to Extreme important \\
\hline 7 & Very strong important \\
\hline 6 & Strong to very strong important \\
\hline 5 & Moderate to strong important \\
\hline 4 & Moderate important \\
\hline 3 & Equal to moderate important \\
\hline 2 & Equal important \\
\hline 1 & \\
\hline
\end{tabular}

Table 1: a Rating scale for supplier selection. wants to know the special selection criteria of the alternate supplier if the regular supplier is unable to meet the demand. Therefore, this research focuses on the supplier selection framework to minimize the risk.

This company produces some special types of products like ladies purse, wallet, ladies bag, card holder, travel bag etc. with maintaining high quality. For its smooth production, the company has many suppliers in different countries of the world. As for example for the item of a ladies bag which is made of 10 types of raw materials. Sometimes some important materials like leather, lining, needle, studs, snaps, and zippers are purchased from foreign vendors. So it is necessary to evaluate the supplier performance to minimize the risk factors in logistics. As for evaluation process, in this research, we have considered initially four suppliers from different countries with code Sri-Lanka (S1), Italy (S2), China (S3), and Germany (S4).

\section{Risk management process}

The best supplier selection is a complex decision making the task of where we need to consider multiple criteria [16]. To develop the decision support framework, first, we need to identify the selection criteria to select the best supplier. For this reason, we have reviewed extent literature to identify the important selection criteria.

After that, it needs to examine the best suppliers by considering selected criteria. In this research, for evaluating best supplier, we have used AHP approach; it is a very workable technique to investigate the MCDA problems. Hence, its problems are that it only works on matrices that are all of the same mathematical forms. It creates trouble when the number of criteria and the alternatives become large. In this research, we have taken eight most important selection criteria to evaluate the best supplier. In addition, we have considered five most suitable selection criteria to evaluate the best alternative supplier when the regular supplier is unable to deal the supply of materials. The higher weight of supplier indicates the supplier is more suitable to fulfill the current demand of companies. The proposed decision modeling framework will assist decision makers to evaluate the best supplier and also will help to overcome the critical situations.

\section{Criteria used in this study}

Supplier evaluation criteria are most crucial part of supplier selection. Therefore, it is mandatory to consider the important selection criteria to evaluate the best supplier. This evaluation criteria help minimize risk and increase the profitability of a company. For this reason, the company needs to identify the important selection criteria. In this research, we evaluate the regular supplier considering the eight important selection criteria which are derived from extant literature review. In addition, another five selection criteria are considered to evaluate the best supplier when the regular supplier is suddenly unavailable to supply materials. This research highlights a leather products company's supply chains as a case example to evaluate the best supplier.

In this research, we identified 13 most important selection criteria to evaluate the best supplier. The selection criteria for literature are given below:

1. Quality improvement (C1)

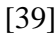

\begin{tabular}{|c|c|c|c|c|c|c|c|c|c|c|}
\hline Size (n) & 1 & 2 & 3 & 4 & 5 & 6 & 7 & 8 & 9 & 10 \\
\hline R.I & 0 & 0 & 0.58 & 0.9 & 1.12 & 1.24 & 1.32 & 1.41 & 1.45 & 1.49 \\
\hline
\end{tabular}


2. Minimum delivery time (C2) [5]

3. Use IT in supply chain (C3) [20]

4. Cost minimization (C4) [40]

5. Service level (C5) [41]

6. Customer satisfaction (C6) [42]

7. Collaborative planning (C7) [5]

8. Trust development (C8) [42].

Others factors are considered to select a best alternative supplier.

1. Quality improvement (C'1)

2. Uncertainty minimization (C'2)

3. IT adaptation (C'3)

4. Lead time minimization (C'4)

5. High transportation facility (C'5)
These identified five evaluation criteria are most important to evaluate the best supplier when selected supplier suddenly becomes unavailable. To maintain quality products, the company should never compromise the quality of materials. Hence for the alternative supplier selection process, we have considered most five important criteria which never affect the quality of products. Figure $1 \mathrm{a}$ and $1 \mathrm{~b}$ show the factors that have been considered to select thebestsupplier.

In this study, we have considered four suppliers namely Sri-Lanka (S1), Italy (S2), China (S3), and Germany (S4).

Evaluation at level 1 for attributes: To evaluate the regular supplier, we have developed AHP structure and to evaluate the alternative structure we have also developed the AHP structure of alternate supplier. Therefore, pairwise comparison matrix for main attributes is constructed with the help of expert's feedback and it is shown in Table 3.

Pairwise comparison matrix for quality improvement is shown in Table 4.

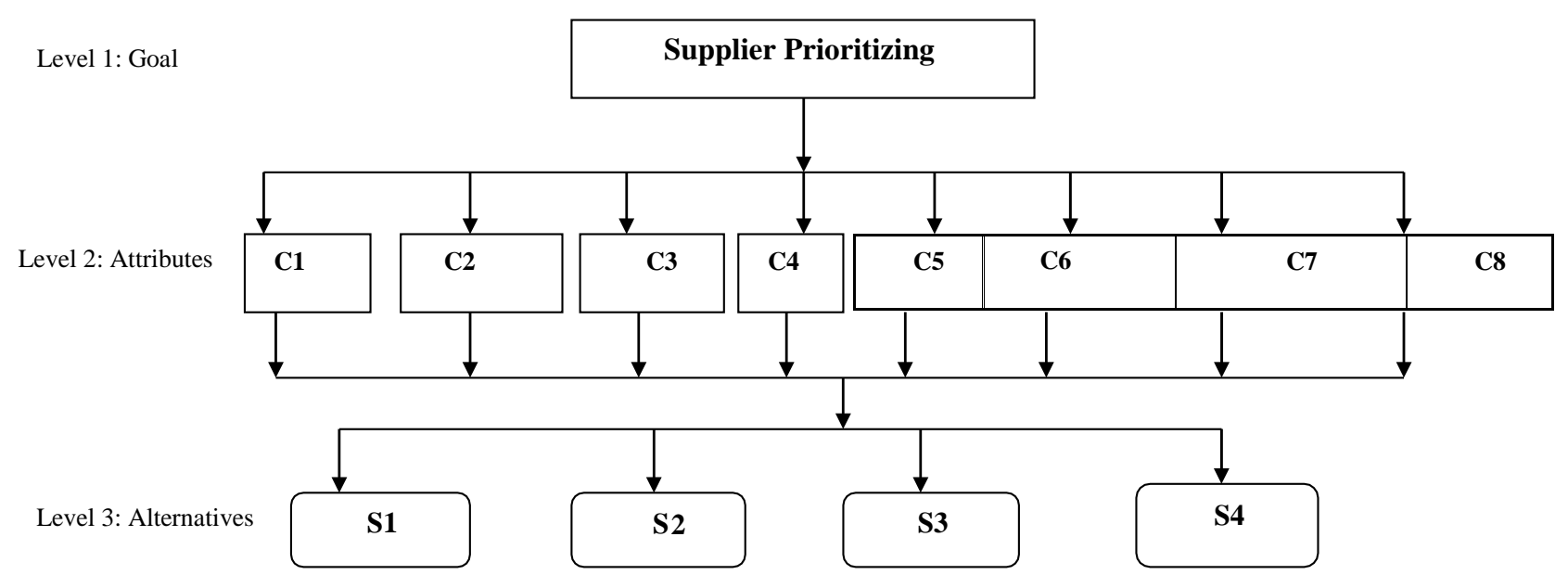

Figure 1a: A hierarchy for supplier selection.

Level 1: Goal

\section{Supplier Prioritizing}

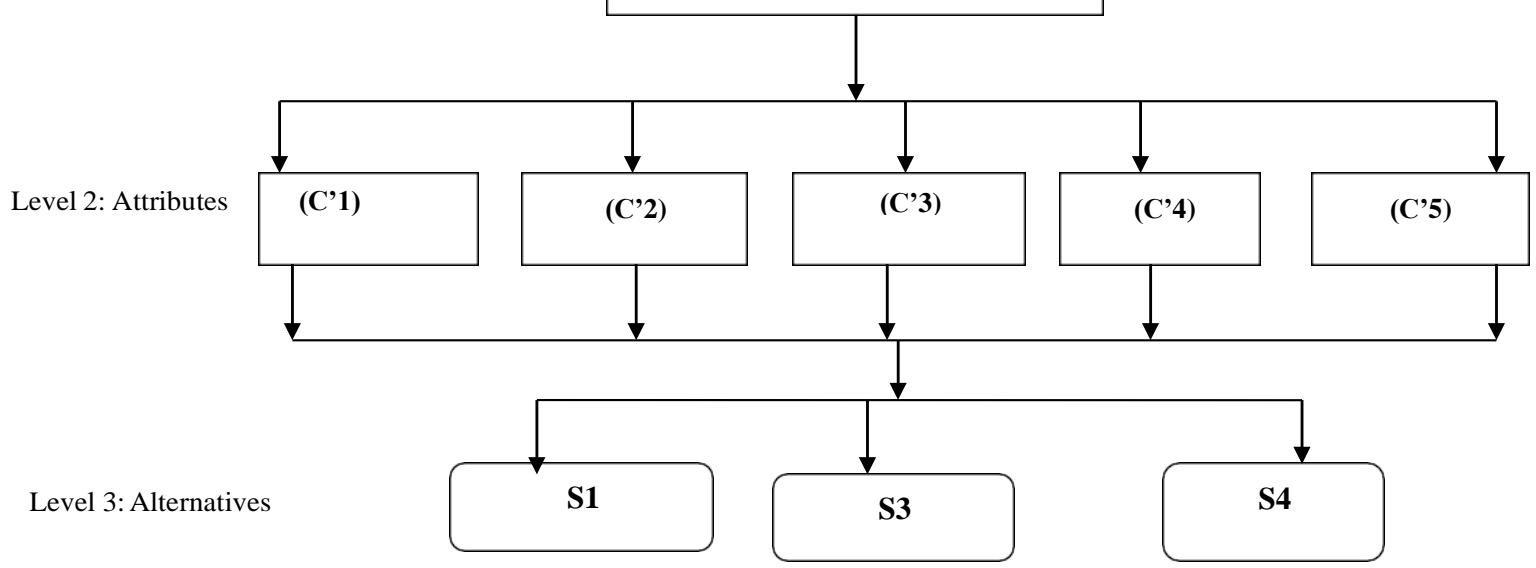

Figure 1b: A hierarchy for selecting alternative supplier. 


\begin{tabular}{|c|c|c|c|c|c|c|c|c|c|}
\hline Criteria & C1 & $\mathrm{C} 2$ & C3 & C4 & C5 & C6 & $\mathrm{C} 7$ & C8 & Weights \\
\hline C1 & 1 & $1 / 2$ & 1 & 1 & $1 / 2$ & 1 & $1 / 2$ & 1 & 0.0951 \\
\hline $\mathrm{C} 2$ & 2 & 1 & 2 & 2 & 1 & 2 & 1 & $1 / 2$ & 0.1600 \\
\hline C3 & 1 & $1 / 2$ & 1 & 1 & 1 & $1 / 2$ & 1 & 1 & 0.1037 \\
\hline $\mathrm{C} 4$ & 1 & $1 / 2$ & 1 & 1 & 2 & 1 & 1 & 2 & 0.1345 \\
\hline C5 & 2 & 1 & 1 & $1 / 2$ & 1 & $1 / 2$ & 2 & 1 & 0.1234 \\
\hline C6 & 1 & $1 / 2$ & 2 & 1 & 2 & 1 & 1 & 2 & 0.1467 \\
\hline $\mathrm{C} 7$ & 2 & 1 & 1 & 1 & $1 / 2$ & 1 & 1 & $1 / 2$ & 0.1131 \\
\hline $\mathrm{C} 8$ & 1 & 2 & 1 & $1 / 2$ & 1 & $1 / 2$ & 2 & 1 & 0.1234 \\
\hline
\end{tabular}

Table 3: Pairwise comparison matrix for main criteria.

\begin{tabular}{|c|c|c|c|c|c|}
\hline $\mathrm{C} 1$ & S1 & S2 & S3 & S4 & Weights \\
\hline S1 & 1 & 2 & 2 & 1 & 0.341 \\
\hline $\mathrm{S} 2$ & $1 / 2$ & 1 & 1 & 1 & 0.203 \\
\hline S3 & $1 / 2$ & 1 & 1 & $1 / 2$ & 0.170 \\
\hline S4 & 1 & 1 & 2 & 1 & 0.286 \\
\hline
\end{tabular}

Table 4: Pairwise comparison matrix for quality improvement.

\begin{tabular}{|c|c|c|c|c|c|c|c|c|c|c|}
\hline \multirow[t]{3}{*}{ Suppliers } & \multicolumn{8}{|c|}{ Criteria with weights } & \multirow{3}{*}{$\begin{array}{l}\text { Global } \\
\text { Weights }\end{array}$} & \multirow[t]{3}{*}{ Ranking } \\
\hline & C1 & C2 & C3 & C4 & C5 & C6 & C7 & C8 & & \\
\hline & 0.0951 & 0.1600 & 0.1037 & 0.1345 & 0.1234 & 0.1467 & 0.1131 & 0.1234 & & \\
\hline S1 & 0.341 & 0.429 & 0.371 & 0.423 & 0.321 & 0.325 & 0.447 & 0.503 & 0.3963501 & 1 \\
\hline S2 & 0.203 & 0.147 & 0.168 & 0.161 & 0.185 & 0.123 & 0.063 & 0.065 & 0.1379208 & 4 \\
\hline S3 & 0.170 & 0.194 & 0.180 & 0.145 & 0.290 & 0.359 & 0.266 & 0.235 & 0.2329104 & 2 \\
\hline S4 & 0.286 & 0.230 & 0.282 & 0.270 & 0.205 & 0.193 & 0.224 & 0.197 & 0.2328113 & 3 \\
\hline
\end{tabular}

Table 5: Final Evaluation.

\begin{tabular}{|c|c|c|c|c|c|}
\hline Criteria & C'1 & C'2 & C'3 & C'4 & C'5 \\
\hline C'1 & 1 & $1 / 2$ & 5 & 2 \\
\hline C'2 & 2 & 1 & 2 & 1 & 2 \\
\hline C'3 & $1 / 5$ & $1 / 2$ & 1 & $1 / 2$ & 0.252 \\
\hline C'4 & 1 & $1 / 2$ & 2 & 0.318 \\
\hline C'5 & $1 / 2$ & $1 / 2$ & 1 & $1 / 2$ & 0.100 \\
\hline
\end{tabular}

Table 6: Pairwise comparison matrix for criteria.

\begin{tabular}{|c|c|c|c|c|}
\hline C'1 & S4 & S3 & S1 & 1 \\
\hline S4 & 1 & $1 / 4$ & 0.184 \\
\hline S3 & 4 & 1 & 0.584 \\
\hline S1 & 1 & $1 / 2$ & 1 \\
\hline
\end{tabular}

Table 7: Pairwise comparison matrix for quality improvement.

\begin{tabular}{|c|c|c|c|c|c|c|c|}
\hline \multirow[t]{2}{*}{ Suppliers } & \multicolumn{5}{|c|}{ Criteria with Weights } & \multirow[t]{2}{*}{ Global Weights } & \multirow[t]{2}{*}{ Ranking } \\
\hline & $\begin{array}{c}\text { C'1 } \\
0.252\end{array}$ & $\begin{array}{c}C^{\prime} 2 \\
0.318\end{array}$ & $\begin{array}{c}\text { C'3 } \\
0.100\end{array}$ & $\begin{array}{c}C^{\prime} 4 \\
0.210\end{array}$ & $\begin{array}{c}C^{\prime} 5 \\
0.120\end{array}$ & & \\
\hline S4 & 0.184 & 0.260 & 0.594 & 0.637 & 0.558 & 0.389178 & 1 \\
\hline S3 & 0.584 & 0.413 & 0.249 & 0.105 & 0.122 & 0.340092 & 2 \\
\hline S1 & 0.232 & 0.327 & 0.157 & 0.258 & 0.320 & 0.270730 & 3 \\
\hline
\end{tabular}

Table 8: Final evaluation.

Similarly, other comparison matrices are formulated and calculated relative weights. Finally, we have got the final weights for four suppliers which are given in Table 5 .

From the analysis with AHP approach, it is clear that Sri-Lanka (S1) has got the highest rank among four alternative suppliers. It indicates that supplier (S1) is best to compare to other three suppliers.

Evaluation at level 2 for alternatives: Now, we have justified the performance if the supplier Sri-Lanka is unable to supply the materials. We have considered following five criteria to evaluate alternative supplier among remaining three suppliers.

1. Quality improvement (C'1)
2. Uncertainty minimization (C'2)

3. IT adaptation (C'3)

4. Lead time minimization (C'4)

5. High transportation facility (C'5)

Therefore, we evaluate the best supplier when logistics risk occurs and the evaluation process in Table 6 .

The comparison matrix for quality improvement is given in Table 7.

Similarly, other comparison matrices are formulated and calculated relative weights. 
Finally, we have got the final weights for three suppliers which are given in Table 8.

From the results in Table 8, it is clear that Germany is the best supplier when logistics risks occur in the supply chains.

\section{Discussion and Conclusions}

Today's competitive business environment; the success of a business largely depends on the appropriate supplier selection. Therefore, choosing an appropriate supplier plays a significant role in the supply chain performance of the leather products manufacturing company. To improve the business performance and to minimize the sudden logistics risk with respect to supplier selection, this research will help to evaluate the best suppliers in a quantitative way. Also, to fulfill the customer demand timely, it is mandatory to select the best supplier to minimize the logistics risks as well as for the smooth production. Therefore, this research aimed to identify the important supplier selection criteria and propose decision modeling framework to minimize the logistics risks. Due to the complexity of supplier selection, this research used AHP approach to evaluate the best supplier among multiple suppliers; AHP is a dynamic tool which can handle to evaluate the multiple criteria decision analysis problems.

This research framework highlighted the leather products company's supply chain to justify the validity of the research. In this research, we have considered multiple supplier selection criteria such as quality improvement, minimum delivery time, use IT in the supply chain, cost minimization, service level, customer satisfaction, collaborative planning, and trust development to develop the decision model for appropriate supplier selection. To select the best supplier, we have used some special selection criteria like quality improvement, uncertainty minimization, IT adaptation, lead time minimization and high transportation facility which will help decision maker to handle the critical situation without any trouble. This all selection criteria were derived from the extant literature review. Five most important selection criteria were employed to develop decision model to validate the model with respect to a leather products manufacturing company. Finding reveals that supplier Sri-Lanka is more appropriate than the other suppliers and if the sudden logistics risks occur supplier Germany is more suitable to deal the sudden risks. Therefore, the performance of supplier Sri-Lanka is very high with respect to other and if the supplier Sri-Lanka is unable to supply materials that time supplier Germany is more appropriate to supply the materials.

The applicability of the proposed decision model is that it can help decision maker to manage the logistics risk in a systematic way. The selection criteria can be changed based on the types of company and the policy of decision makers. Therefore, the decision maker should concern about selecting decision criteria. Based on selection criteria, the model can be varied with respect to other manufacturing company. The proposed decision support model is largely appropriate for leather Products Company. Hence, this decision support model will hopefully effective to minimize the logistics risks as well as to improve the business performance.

\section{Managerial Implications and Future Direction of Study}

Our expectation is that this study will help the managers of the other manufacturing companies formulate a strategic plan for best supplier selection. Supplier selection is a key issue for managing risk and sustaining their business in the competitive global market. This study shows the strategic plan for best supplier selection and also finds the best supplier of risks occurred in supply chains. To show the practical implication of this study, consider a leather products company supply chain. The managers of leather product companies will be able to evaluate the best suppliers and select the best ones during any risk occurred in the supply chain. Other relevant companies of Bangladesh like, footwear, leather, chemical, pharmaceutical etc. can get the idea from this research for practical implications of best supplier selection. In future other multi-criteria tools Fuzzy-AHP can be used to evaluate the best supplier to sustain in the competitive global market.

\section{References}

1. Akamp M, Mller M (2013) Supplier management in developing countries. Journal of Cleaner Production 56: 54-62.

2. Akarte MM, Surendra NV, Ravi B, Rangaraj N (2001) Web-based casting supplier evaluation using analytical hierarchy process. Journal of the Operational Research Society 52: 511-522.

3. Aksoy A, Ozturk N (2011) Supplier selection and performance evaluation in just-in-time production environments. Expert Systems with Applications 38: 6351-6359.

4. Moktadir MA, Ahmed S, Fatema-Tuj-Zohra, Sultana R (2017) Productivity Improvement by Work Study Technique: A Case on Leather Products Industry of Bangladesh. Industrial Engineering \& Management 6: 207.

5. Alexander M (2012) Decision-Making using the Analytic Hierarchy Process (AHP) and SAS/IML. The United States Social Security Administration Baltimore, pp: 1-12.

6. Breuer C, Siestrup G, Haasis HD, Wildebrand H (2013) Collaborative risk management in sensitive logistics nodes. Team Performance Management 19: $331-351$.

7. Chai J, Liu JNK, Ngai EWT (2013) Application of decision-making techniques in supplier selection: A systematic review of the literature. Expert Systems with Applications 40: 3872-3885.

8. Chamodrakas I, Batis D, Martakos D (2010) Supplier selection in electronic marketplaces using satisficing and fuzzy AHP. Expert Systems with Applications 37: $490-498$

9. Chan FTS (2003) Interactive selection model for supplier selection process: an analytical hierarchy process approach. International Journal of Production Research 41: 3549-3579.

10. Chan FTS, Chan HK (2004) Development of the supplier selection model-a case study in the advanced technology industry. Proceedings of the Institution of Mechanical Engineers, Part B: Journal of Engineering Manufacture 218: 1807-1824.

11. Chan FTS, Chan HK, Ip RWL, Lau HCW (2007) A decision support system for supplier selection in the airline industry. Proceedings of the Institution of Mechanical Engineers Part B-Journal of Engineering Manufacture 221: 741 758

12. Chang DY (1996) Applications of the extent analysis method on fuzzy AHP. European Journal of Operational Research 95: 649-655.

13. Chen IJ, Paulraj A, Lado AA (2004) Strategic purchasing, supply management and firm performance. Journal of Operations Management 22: 505-523.

14. Choi TM, Chiu CH, Chan HK (2016) Risk management of logistics systems Transportation Research Part E: Logistics and Transportation Review 90:1-6.

15. Choi TY, Wu Z, Ellram L, Koka BR (2002) Supplier-supplier relationships and their implications for buyer-supplier relationships. IEEE Transactions on Engineering Management 49: 119-130.

16. Dargi A, Anjomshoae A, Galankashi MR, Memari A, Tap MBM (2014) Supplie selection: A fuzzy-ANP approach. In Procedia Computer Science 31: 691-700.

17. Foerstl K, Reuter C, Hartmann E, Blome C (2010) Managing supplie sustainability risks in a dynamically changing environment-Sustainable supplie management in the chemical industry. Journal of Purchasing and Supply Management 16: 118-130.

18. Govindan K, Kannan D, Haq AN (2010) Analyzing supplier development criteria for an automobile industry. Industrial Management and Data Systems 110: 43-62.

19. Govindan K, Rajendran S, Sarkis J, Murugesan P (2015) Multi-criteria decision making approaches for green supplier evaluation and selection: $A$ literature review. Journal of Cleaner Production 98: 66-83. 
Citation: Moktadir MA, Rahman T, Sultana R (2017) Selection of Best Supplier by Using AHP Tool for Managing Risk Factors in Logistics: A Case of Leather Products Industry. Ind Eng Manage 6: 232. doi:10.4172/2169-0316.1000232

Page 7 of 7

20. Hallikas J, Karvonen I, Pulkkinen U, Virolainen VM, Tuominen M (2004)Risk management processes in supplier networks. International Journal of Production Economics 90: 47-58.

21. Ho W, Xu X, Dey PK (2010) Multi-criteria decision making approaches for supplier evaluation and selection: A literature review. European Journal of Operational Research 202: 16-24.

22. Hou J, Su D (2007) EJB-MVC oriented supplier selection system for mass customization. Journal of Manufacturing Technology Management 18:54-71.

23. Humphreys PK, Li WL, Chan LY (2004) The impact of supplier development on buyer-supplier performance. Omega 32: 131-143.

24. Inemek A, Tuna O (2009) Global supplier selection strategies and implications for supplier performance: Turkish suppliers' perception. International Journal of Logistics Research and Applications 12: 381-406.

25. Kabir G, Akhtar Hasin MH (2011) Comparative Analysis of Ahp and Fuzzy Ahp Models Formulticriteria Inventory Classification. International Journal of Fuzzy Logic Systems (IJFLS) 1: 1-16.

26. Kotula M, Ho W, Kumar Dey P, Lee CKM (2015) Strategic sourcing supplier selection misalignment with critical success factors: Findings from multiple case studies in Germany and the United Kingdom. International Journal of Production Economics 166: 238-247.

27. Lee AHI (2009) A fuzzy supplier selection model with the consideration of benefits, opportunities, costs and risks. Expert Systems with Applications 36: 2879-2893.

28. Lee AHI, Kang HY, Hsu CF, Hung HC (2009) A green supplier selection model for high-tech industry. Expert Systems with Applications 36: 7917-7927.

29. Lima Junior FR, Osiro L, Carpinetti LCR (2014) A comparison between Fuzzy AHP and Fuzzy TOPSIS methods to supplier selection. Applied Soft Computing Journal 21: 194-209.

30. Liu FHF, Hai HL (2005) The voting analytic hierarchy process method for selecting supplier. International Journal of Production Economics 97: 308-317.

31. Matook S, Lasch R, Tamaschke R (2009) Supplier development with benchmarking as part of a comprehensive supplier risk management framework. International Journal of Operations \& Production Management 29: 241-267.

32. Muralidharan C, Anantharaman N, Deshmukh SG (2002) A Multi-Criteria Group Decisionmaking Model for Supplier Rating. The Journal of Supply Chain Management 38: 22-33.

33. Ng WL (2008) An efficient and simple model for multiple criteria supplier selection problem. European Journal of Operational Research 186: 1059-1067.

34. Peng J (2012) Selection of Logistics Outsourcing Service Suppliers Based on AHP. Energy Procedia 17: 595-601.

35. Pezzullo L, Filippo RD (2009) Perceptions of industrial risk and emergency management procedures in Hazmat Logistics: A qualitative mental mode approach. Safety Science 47: 537-541.

36. Stock RJ, Lambert DM (2013) Strategic logistics management. Internationa Journal of Physical Distribution \& Logistics Management.

37. Saaty TL (2004) Decision making - the Analytic Hierarchy and Network Processes (AHP/ANP). Journal of Systems Science and Systems Engineering 13: 1-35.

38. Tung SL, Tang SL (1998) A comparison of the Saaty's AHP and modified AHP for right and left eigenvector inconsistency. European Journal of Operational Research 106: 123-128.

39. UmaDevi K, Elango C, Rajesh R (2012) Vendor selection using AHP. In Procedia Engineering 38: 1946-1949.

40. Vonderembse MA, Tracey M (1999) The Impact of Supplier Selection Criteria and Supplier Involvement. The Journal of Supply Chain Management, pp: 33-39.

41. Wee HM, Blos MF, Yang W (2012) Risk Management in Logistics. Handbook on Decision Making, pp: 285-305

42. Wu Z, Choi TY, Rungtusanatham MJ (2010) Supplier-supplier relationships in buyer-supplier-supplier triads: Implications for supplier performance. Journal of Operations Management 28: 115-123.
Citation: Moktadir MA, Rahman T, Sultana R (2017) Selection of Best Supplier by Using AHP Tool for Managing Risk Factors in Logistics: A Case of Leather Products Industry. Ind Eng Manage 6: 232. doi:10.4172/21690316.1000232 